\title{
Clean technologies and green services' implementation in accommodation establishments at the urban area of Otavalo, Ecuador
}

\section{Implementación de tecnologías limpias y servicios verdes en establecimientos de alojamiento en la zona urbana de Otavalo, Ecuador}

Xavier B. Lastra-Bravo ${ }^{1 *}$, Lesly Dayana Casares Morillo²

\footnotetext{
1 Ph.D., Carrera de Turismo Ecológico. Facultad de Ciencias Agrícolas, Universidad Central del Ecuador, Quito, Ecuador.

${ }^{2}$ Lcda., Carrera de Turismo Ecológico. Facultad de Ciencias Agrícolas, Universidad Central del Ecuador, Quito, Ecuador.

* Corresponding author (E-mail corresponding author): xblastraquce.edu.ec
}

\section{ABSTRACT}

Considering the current importance of clean technologies and green services in the tourism sector, its implementation in accommodation establishments in the urban area of Otavalo, Ecuador, was analyzed. The types of establishments included were hotel, hostel, inn, and refuge. Descriptive research was carried out, with a mixed approach, with research tools such as the questionnaire addressed to managers and administrators of the establishments, and interviews with experts. The results showed that the clean technologies and green services that have been most widely implemented are the use of LED lamps or energy-saving spotlights, construction with large windows, the purchase of low-consumption electrical appliances, leakage controls and pressure regulation of pipes, design of gardens and green areas with plant species adapted to natural conditions, location of materials in containers that are marked and differentiated by color and name, and transport and management of waste by authorized entities. Satisfaction with the performance and usefulness of these technologies and services is high among hotel managers, which reflects the importance of continuing to promote their implementation.

Keywords: hospitality; sustainable tourism; good environmental practices; energy efficiency; water efficiency; waste management

\section{RESUMEN}

Considerando la importancia actual de las tecnologías limpias y servicios verdes en el sector turístico, se analizó su implementación en los establecimientos de alojamiento de la zona urbana de Otavalo, Ecuador. Se incluyeron los tipos de establecimiento hotel, hostal, hostería y refugio. Se realizó una investigación descriptiva, con enfoque mixto, con herramientas de investigación como el cuestionario dirigido a gerentes y administradores de los establecimientos, y entrevistas a expertos. Como resultados se identificaron que las tecnologías limpias y servicios verdes que mayor implementación han tenido son el uso de lámparas Led o focos ahorradores la construcción con ventanales amplios, la compra de aparatos eléctricos de bajo consumo, llevar a cabo controles de fugas y regulación de presión de las tuberías, diseño de jardines y zonas verdes con especies vegetales adaptadas a condiciones naturales, la ubicación de materiales en recipientes señalizados y diferenciados por color y nombre, y el transporte y gestión de residuos por entidades autorizadas. La satisfacción del rendimiento y utilidad de estas tecnologías y servicios es alta entre los administradores de los establecimientos hoteleros, que refleja la importancia de seguir promoviendo su implementación.

Palabras clave: hotelería; turismo sostenible; buenas prácticas ambientales; eficiencia energética, eficiencia hídrica, manejo de residuos 


\section{INTRODUCTION}

Accommodation establishments, as well as other tourism activities, depend on the environment to provide their services. For this reason they must comply with the environmental policy established in each territory, and thus try to reduce and control their environmental impact (López Robles, Calderón Gómez, \& López Robles, 2012). These impacts are produced by the establishment's activities carried out for providng an excellent service, e.g. air conditioning systems in the rooms, which emit greenhouse gases into the atmosphere. Another consequence is contamination of the subsoil, sometimes caused by wastewater, or damage to ecosystems by land use and extraction of large volumes of water.

The services offered by the hospitality industry vary widely, from only offering overnight stays, to providing combined services such as stay, food and drink, as well as a number of additional activities, such as events, health and leisure activities, shops, exchange offices, conference rooms, laundry services, passenger transport, parking, excursions, entertainment activities, etc. (Fernández, Van Morlegan, \& Guzmán Ramos, 2007). For this reason, Formastur (2008) explains that the environmental aspects can be similar, but at the same time differ for each accommodation, as it depends on: the services offered, the areas and facilities, and also the occupancy capacity, to measure the environmental impact and therefore take measures according to its reality.

It should be clarified that, although tourism facilities are not causing major environmental damage, their effects are comprised by a whole series of small individual actions that can produce negative synergies when added to those of other industries and sectors (each of them consumes energy, water, food and other resources and can emit small amounts of pollutants such as solid waste, wastewater, smoke, odours, noise, and some chemical substances) (Fernández et al., 2007).

Thus, environmental management becomes a fundamental tool for companies to achieve success against the challenges they face today ( $\mathrm{Paz} \&$ Acosta, 2015). This can be done through the inclusion of different actions such as the definition of the operation management system, improving environmental performance, positively influencing the socio-economic development of the facility, sys- tematically controlling and evaluating the performance of economic and environmental indicators and, renewing the hotels' competitiveness and corporate image through environmental protection actions.

In addition, the tourist's profile is currently changing towards choosing sustainable and environmentally friendly destinations, products, and services. Therefore, the hospitality industry has realized the need to implement clean technologies and green services for minimizing the environmental impacts produced, from the construction to the operational phase, where impacts such as noise, vibrations, erosion, effluent discharges, waste generation, pollution by harmful cleaning materials, and inadequate use of water and energy resources are produced (DANE, 2017).

According to Juvinao and Reines (2013), clean technologies and green services are those technologies and practices related to all the tools and instruments enabling an optimal use of natural resources. These technologies contribute to the philosophy of looking ahead, anticipating, preventing, and being competitive with other countries, generating environmental and social benefits, and bringing a series of environmental and legal compliance advantages. Among the advantages are savings in production costs, improved external relations, improved image, increased sales, among others. These technologies can also be called non-polluting, ecological or clean (Centro de Comercio Internacional, 2019), defined as those goods and services that improve the quality of natural resources or that seek solutions to problems related to waste or noise. These technologies can be very different and range from highly complex and expensive high-tech systems to simple solutions.

Specifically in tourism, these types of technologies and services have been implemented in the different services and facilities which make up the tourism sector, such as: hotels, restaurants, entertainment, and transportation. Within the accommodation establishments, the implementation of clean technologies means environmental benefits (mainly energy) and therefore economic, as well as obtaining advantages in selling an innovative and modern image of being environmentally friendly, green and sustainable, a symbol of professional excellence, and a commitment to the future (Centro de Tecnologías Limpias, 2008). 
Among green technologies and clean services implemented in hotels for reaching the so-called energy efficiency, FENERCOM (2017) mentions the following: use of LED lamps, use of energy efficient appliances, installation of large windows, and smart zoning the common areas to avoid lighting spaces that are not being used. Terry (2002) adds as other clean technologies, automated on/off controls for lighting and air conditioning; and as complementary measures recommends systematic monitoring of energy carriers, periodic efficiency evaluation of facilities and equipment, energy efficiency programme settings based on the results of periodic evaluations, insulation of hot and cold water pipes, and raising awareness among workers and clients.

Water resources' consumption is another issue of great importance within accommodation establishments, and therefore it is necessary to implement efficient and sustainable actions. Mainly for two reasons: to reduce the expenditure on water and associated energy consumption, and to commit and identify the tourism sector with sustainability and efficiency policies, which are necessary for the conservation of the environment (Instituto Tecnológico Hotelero, 2014). These actions are demanded by users who are increasingly aware of these issues. Among the technologies, green services, and measures mentioned are: flow regulators (perlators or diffusers) in washbasins, shower flow restrictors, double-flushing cisterns, establishment of irrigation schedules according to the weather, irrigation systems for recovered and/or recycled water, design of gardens and green areas with native plant species, and leakage control and pressure regulation. On the other hand, one of the most effective and successful measures is to include or involve the customer in their water consumption. Especially in certain activities such as those related to the replacement of bedding and towels (green laundry), since this task carried out in a conscious way allows a significant reduction in water consumption (Instituto Tecnológico Hotelero, 2014).

The generation of solid waste is also one of the issues presented in the different areas of accommodation establishments, which is why its management and control are necessary. According to Broche \& Ramos (2015), common types of solid waste generated by hotels are: glass, plastics, paper, cardboard, and aluminum, for which the separation of each type into respectively marked and differentiated containers constitutes an alternative, as well as avoiding the use of cardboard and packaging in the acquisition of clothing or inputs for hotels. In order to manage this type of waste, the application of the "three Rs" is proposed as a solution. This is a culture of solid waste management that allows changes in the population's attitude towards the use of waste of inorganic origin. In this sense, the three Rs contribute to changes in habits, practices, and lifestyles according to the efficient use of resources that each person needs to live (Rischmagui, 2017).

In relation to simple solutions, Best Environmental Practices should be considered, which are useful both because of their simplicity and low cost, and because of the fast and significant results that are obtained (Centro de Tecnologías Limpias, 2008). In summary, these are changes in habits and ways of acting that improve environmental management and bring with them various benefits, including the reduction of consumption of natural resources, the segregation of resources generated for reuse, and the raising of awareness among clients. Also, they can be understood as a set of simple actions that originate a friendly relationship with the environment, involving a change of attitude and behavior in daily activities. According to the Rainforest Alliance, SNV and Counterpart International (2008), they are a set of measures aimed at preventing, correcting or improving certain issues of the tourism operation, and can be implemented in all of the enterprise's service and operational areas. Their purpose is to achieve environmental, socio-cultural, and economic benefits, in addition to offering a better quality tourism product, reflecting a good image before the customer and thus achieving more efficient business management. These actions contribute to saving resources and inputs, to improving the administration of the enterprise, to making clients, staff and suppliers aware of a vision of sustainability, to obtaining recognition in the market, and to being more competitive due to their quality and responsibility.

Another important concept to highlight is "Social Responsibility", which has gained importance thanks to the emphasis of corporate entreprises on achieving economic results and preventing or managing the impacts that their activities cause in their work team, suppliers, shareholders, community, environment, and society in general (Ja- 
ramillo, 2011). Thus, the responsible use of resources and the application of policies in this field have become a strategic element for business management, contributing to the development of competitive advantages for companies that implement them (Fernández \& Cuadrado, 2011).

Corporate Social Responsibility (CSR) refers to a new business culture focused on caring for the environment, relationships with stakeholders, and compliance, through ethical and transparent actions (Jaramillo, 2011). It is also understood as the guidelines that frame an ethical, committed and visible action on aspects different from those that are normally the purpose of an organization, such as the financial field. In this way, the enterprise, besides being a generator of capital, also acts as a promoter of conditions directed towards sustainable development (Bedoya, Bejarano, \& Bedoya, 2017). In other words, CSR is the voluntary decision of an organisation to take responsibility for their internal and external activities, and the legal, economic, social and environmental impact it may have on its environment, in order to improve it and have a positive impact on suppliers, collaborators, the community, consumers and the State (Acosta Véliz, Lovato Torres, \& Buñay Cantos, 2018). One of its purposes is to ensure that the organization promotes and encourages ethical values as an essential and proper part of its organizational culture. Therefore, it is committed to internal (collaborators or work team) and external (customers and suppliers) actors, in addition to encompassing its objective of generating better economic results (Henríquez \& Oreste, 2015).

Therefore, the objectives of this research were to identify the clean technologies and green services that have been implemented in the accommodation establishments in the urban area of Otavalo, together with determining the options considered by the hoteliers to implement in the future, and finally, to determine their satisfaction with the clean technologies and green services implemented. For this purpose, a questionnaire was applied to managers or administrators of the hotel establishments, and interviews were conducted with professionals in the area.

\section{METHODOLOGY Study area}

The city of Otavalo is located in the Andean region, in the north of Ecuador, in the province of Imbabura, $95 \mathrm{~km}$ northeast of Quito. It is popularly known for its handicrafts and textile market, which is the largest indigenous market in the world, with its heart in the "Plaza de los Ponchos" (Lalander, 2009). In addition, it has been recognized as the intercultural capital of Ecuador, according to the declaration given by the Congress of the Republic in 2003. For Otavalo, tourism is one of its main economic activities, so the accommodation establishments play an important role within the urban area. In the report "Profile of the tourist who visited Otavalo in 2015", prepared by the Directorate of Tourism and Local Economic Development (Gobierno Autónomo Desentralizado de Otavalo, 2015), it was determined that $83 \%$ of those surveyed make use of an accommodation facility. In addition, in 2014 the Ecuadorian Ministry of Tourism issued a report stating that Otavalo received an average of 35,898 visitors per month during that year, of which 30,872 were to stay at accommodation facilities (Realpe Sandoval \& Benítez Bastías, 2015). These data show that the accommodation service is in demand within the tourism market, and therefore must be at the forefront of trends, and also play an environmentally and socially responsible role.

\section{Methods and instruments}

Descriptive research was developed, focused on determining and assessing the characteristics of the accommodation establishments of the study area in relation to clean technologies and green services. The mixed approach was applied, since surveys, and interviews were used as research instruments to obtain information. The survey was aimed at managers or administrators of accommodation establishments. On the other hand, the interviews were conducted with professionals in architecture, environmental engineering, and the director of Tourism and Local Economic Development of the Local Government of Otavalo, who provided information on the use and importance of green technologies, renewable energies, regulations, and training for accommodation establishments.

The questionnaire applied included 16 questions. This tool allowed us to know the clean technologies and green services implemented and, according to the perception of those surveyed, which are those that would be implemented with better results in the tourism sector. In addition, it was possible to evaluate the satisfaction towards these technologies with the Likert scale (1-5), where 1 is the score that reflects "very dissatisfied" and 5 "very satisfied". The three main issues addressed were: energy, water resources, and waste. 
To set the population and sample, the National Consolidated Cadastre (2019) was used, where 34 accommodation establishments in the urban area of Otavalo were determined (Table 1), initially establishing a census. It should also be noted that research was done on the classification of accommodation as hotel, hostel, inn, and refuge. However, no response was obtained from 4 establishments, therefore the investigation had a final sample of 30 establishments, that is, $88 \%$ of the total population.

\section{RESULTS AND DISCUSSION}

\section{Clean technologies and green services implemented by accommodation establishments}

One hundred percent of accommodation establishments have implemented some type of clean technology or green service, however, not all administrators or managers are conceptually aware of these terms. Thus, in hostels, inns, and refuges, $100 \%$ of managers have information about the terms mentioned, but in the case of hotels, only $83 \%$ claim to know them ( $\mathrm{Fi}$ gure 1). According to Contreras \& Peñaloza (2018), human talent and environmental care are two strategic issues in enterprises, because despite the fact that technological development has provided several tools to minimize impacts on the environment, employees represent a factor capable of providing several benefits in terms of environmental care, in addition to being essential to meet the established objectives. In the case of hotels, it is necessary to promote environmental care skills among staff, so that each employee will be able to contribute to this responsibility from their work space, whether in administrative, managerial or supervisory positions, among others.

Table 1: List of registered tourism accommodation establishments in the urban area of Otavalo (Ministerio de Turismo, 2019)

\begin{tabular}{ll}
\hline Category & Name \\
\hline Hotel - 4 & Indio Inn \\
stars &
\end{tabular}

\begin{tabular}{ll}
\hline Category & Name \\
\hline $\begin{array}{l}\text { Hostel - } 1 \\
\text { star }\end{array}$ & Riviera Sucre \\
\hline
\end{tabular}

\begin{tabular}{|c|c|c|c|}
\hline \multirow[t]{2}{*}{$\begin{array}{l}\text { Hotel - } 3 \\
\text { stars }\end{array}$} & \multicolumn{2}{|l|}{ Coraza } & $\begin{array}{l}\text { La Playita } \\
\text { de Monse }\end{array}$ \\
\hline & \multicolumn{2}{|l|}{ Flores \#2 } & Curiñan \\
\hline \multirow[t]{5}{*}{$\begin{array}{l}\text { Hotel - } 2 \\
\text { stars }\end{array}$} & \multicolumn{2}{|l|}{$\begin{array}{l}\text { Sumak Wasi } \\
\text { Suites }\end{array}$} & Runa Pacha \\
\hline & \multicolumn{2}{|l|}{ El Indio } & San Luis \\
\hline & \multicolumn{2}{|l|}{ Yamor } & Samana \\
\hline & \multicolumn{3}{|l|}{ Continental } \\
\hline & \multicolumn{2}{|l|}{ Acoma } & Otavalos Inn \\
\hline \multirow[t]{14}{*}{$\begin{array}{l}\text { Hostel - } 2 \\
\text { stars }\end{array}$} & \multicolumn{2}{|l|}{ Santa Fe } & $\begin{array}{l}\text { Los Andes } \\
\text { Otavalo }\end{array}$ \\
\hline & \multicolumn{2}{|l|}{ Santa Fe } & El Andariego \\
\hline & \multirow{2}{*}{\multicolumn{2}{|c|}{ Mashys }} & La Rosa \\
\hline & & & Otavalo \\
\hline & \multicolumn{2}{|l|}{ Doña Esther } & Maria \\
\hline & \multicolumn{2}{|l|}{ Mirador de } & Sucre \\
\hline & \multicolumn{3}{|l|}{ Otavalo } \\
\hline & \multicolumn{2}{|l|}{ Aly \# 1} & Paukar \\
\hline & Aly \#2 & Inn - 3 stars & Rose Cottage \\
\hline & \multicolumn{2}{|l|}{ Aly } & Casa Mojanda \\
\hline & \multirow{2}{*}{$\begin{array}{l}\text { Andean Wasi } \\
\text { Inn }\end{array}$} & Refuge- & La Luna \\
\hline & & $\begin{array}{l}\text { unique } \\
\text { category }\end{array}$ & Mountain \\
\hline & \multicolumn{3}{|l|}{ Arauco } \\
\hline & \multicolumn{3}{|l|}{ Chukitos } \\
\hline
\end{tabular}

Regarding energy issues, Molina et al. (2009) highlight that both strategies and environmental innovations can lead to cost reductions due to a more efficient use of energy and inputs, reducing the environmental impacts they cause. In Otavalo, $52 \%$ of the accommodation establishments have implemented some kind of clean technology or green service (Table 2). LED lamps and low-consumption electrical appliances are the most widely used technologies. The installation of large windows to take advantage of sunlight stands out as a measure widely implemented by the establishments, and which refers to bioclimatic architecture. It should be noted that, of the total sample of establishments surveyed, only one hostel has implemented an automatic air conditioning on/off system. 
Figure 1. Establishments that have implemented clean technologies and/or green services vs. Managers with knowledge of the terms clean technologies and/or green services

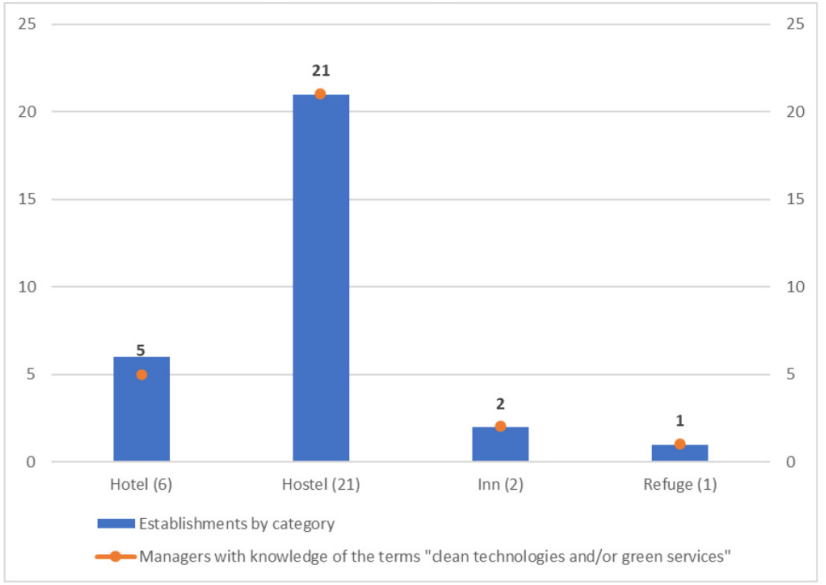

Table 2: Clean technologies and green services - Energy issues

\begin{tabular}{lcccc}
\hline & Hotel & Hostel & Inn & Refuge \\
\hline $\begin{array}{l}\text { LED or energy-saving } \\
\text { lamps }\end{array}$ & $6 / 6$ & $21 / 21$ & $2 / 2$ & $1 / 1$ \\
& $(100 \%)$ & $(100 \%)$ & $(100 \%)$ & $(100 \%)$ \\
$\begin{array}{lcccc}\text { Low-consumption } \\
\text { electrical appliances }\end{array}$ & $6 / 6$ & $15 / 21$ & $2 / 2$ & $1 / 1$ \\
Automated on/off & $3 / 6$ & $10 / 21$ & $0 / 2$ & $0 / 1$ \\
$\begin{array}{l}\text { controls systems for } \\
\text { lighting }\end{array}$ & $(50 \%)$ & $(48 \%)$ & $(0 \%)$ & $(0 \%)$ \\
$\begin{array}{l}\text { Automated on/off } \\
\text { controls systems for }\end{array}$ & $0 / 6$ & $1 / 21$ & $0 / 2$ & $0 / 1$ \\
conditioning & $(0 \%)$ & $(5 \%)$ & $(0 \%)$ & $(0 \%)$ \\
& $0 / 6$ & $0 / 21$ & $0 / 2$ & $0 / 1$ \\
Renewable energies & $(0 \%)$ & $(0 \%)$ & $(0 \%)$ & $(0 \%)$ \\
& $6 / 6$ & $17 / 21$ & $2 / 2$ & $1 / 1$ \\
& $(100 \%)$ & $(81 \%)$ & $(100 \%)$ & $(100 \%)$ \\
Large windows & & & & \\
& & & & \\
\hline
\end{tabular}

A negative result highlights that no establishment currently makes use of any type of renewable energy, this being a point that should be promoted and strengthened, since it is this type of energy that generates less impact on the en- vironment and greater economic benefits, as mentioned by Lastra et al. (2015). In addition, in the case of Ecuador there is a high potential for the use of renewable energy, especially photovoltaic and solar thermal, so for its development and implementation, especially in the tourism sector, greater government support is needed. This situation was also expressed by the experts interviewed, who indicated that Ecuador is a country with high potential to be able to implement solar panels in a greater number.

Specifically on lighting, it was found that $83 \%$ of hotels use energy-saving lamps, 50\% LED lamps and 17\% dichroic lamps (Figure 2). Among hotels 57\% use LED and energy-saving lamps, 5\% use fluorescent lamps, and 10\% of them use neon lamps. On the other hand, the hostels make use of LED and energy-saving lamps in 100\% and $50 \%$ respectively, while the refuge only uses LED lamps. Unitl 2020, both LED and fluorescent lamps have been established as the technologies with greater economic and environmental benefits.

Figure 2. Types of lamps used in lighting

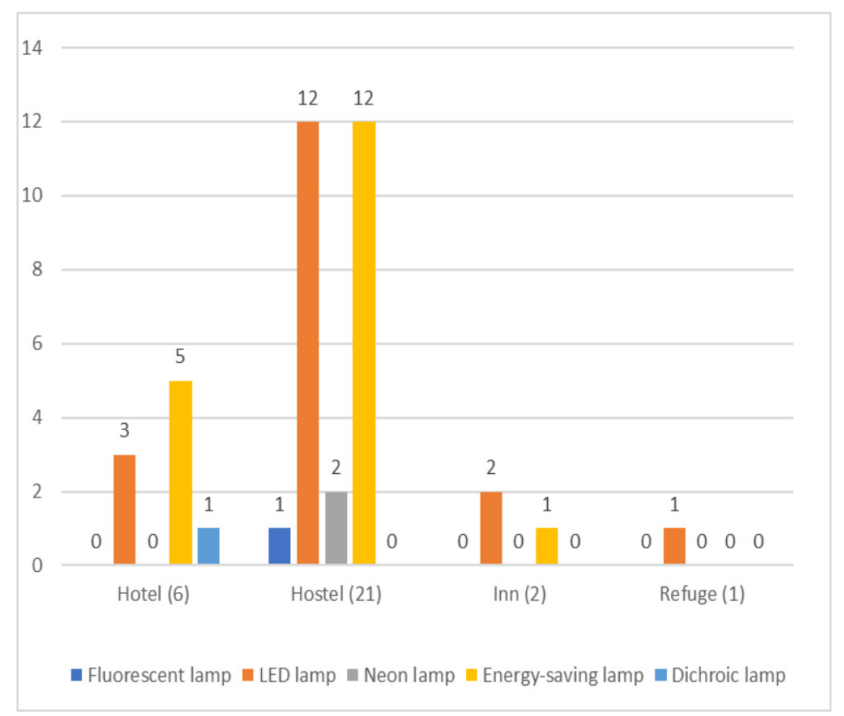

LED lamps are characterized by energy savings of up to $80 \%$ and duration of up to 70,000 hours (Aravena, 2019). Fluorescent lamps have among their characteristics a saving of $30-45 \%$ and a duration of up to 8,000 hours. Another reference to understand the difference between these lamps, is the relationship between the percentage of energy to produce heat and the percentage to illuminate. LED lamps use less than 
$5 \%$ of energy to produce heat and $95 \%$ to illuminate, while energy-saving lamps use $20 \%$ of energy to produce heat and $80 \%$ to illuminate, while an incandescent lamp uses $70 \%$ of energy to produce heat and only $30 \%$ to illuminate. According to Jiménez \& Segura (2015), an incandescent lamp has a consumption of over $60 \mathrm{~W}$, a fluorescent lamp has a consumption of over $35 \mathrm{~W}$, while LED lamps reduce electricity consumption by $60 \%$, compared to incandescent lamps, and by $40 \%$ with fluorescent lamps.

Regarding water issues, $46 \%$ of the establishments have implemented some kind of clean technology or green service (Table 3). The low level of implementation of water efficiency technologies stands out, since the establishments have opted more for the use of good environmental practices.

\section{Table 3: Clean technologies and green servi- ces - Water issues}

\begin{tabular}{|c|c|c|c|c|}
\hline & Hotel & Hostel & Inn & Refuge \\
\hline $\begin{array}{l}\text { Flow regulators in } \\
\text { washbasins }\end{array}$ & $\begin{array}{l}1 / 6 \\
(17 \%)\end{array}$ & $\begin{array}{l}2 / 21 \\
(10 \%)\end{array}$ & $\begin{array}{l}0 / 2 \\
(0 \%)\end{array}$ & $\begin{array}{l}0 / 1 \\
(0 \%)\end{array}$ \\
\hline $\begin{array}{l}\text { Gardens with native } \\
\text { plant species }\end{array}$ & $\begin{array}{c}6 / 6 \\
(100 \%)\end{array}$ & $\begin{array}{l}6 / 21 \\
(29 \%)\end{array}$ & $\begin{array}{c}2 / 2 \\
(100 \%)\end{array}$ & $\begin{array}{c}1 / 1 \\
(100 \%)\end{array}$ \\
\hline $\begin{array}{l}\text { Irrigation systems } \\
\text { for recovered and/or } \\
\text { recycled water }\end{array}$ & $\begin{array}{l}3 / 6 \\
(50 \%)\end{array}$ & $\begin{array}{l}3 / 21 \\
(14 \%)\end{array}$ & $\begin{array}{l}1 / 2 \\
(50 \%)\end{array}$ & $\begin{array}{l}0 / 1 \\
(0 \%)\end{array}$ \\
\hline Sensor activated taps & $\begin{array}{l}0 / 6 \\
(0 \%)\end{array}$ & $\begin{array}{l}1 / 21 \\
(5 \%)\end{array}$ & $\begin{array}{l}0 / 2 \\
(0 \%)\end{array}$ & $\begin{array}{l}0 / 1 \\
(0 \%)\end{array}$ \\
\hline Shower flow restrictors & $\begin{array}{c}1 / 6 \\
(17 \%)\end{array}$ & $\begin{array}{l}2 / 21 \\
(10 \%)\end{array}$ & $\begin{array}{c}2 / 2 \\
(100 \%)\end{array}$ & $\begin{array}{l}0 / 1 \\
(0 \%)\end{array}$ \\
\hline $\begin{array}{l}\text { Irrigation schedules } \\
\text { according to } \\
\text { the weather }\end{array}$ & $\begin{array}{c}3 / 6 \\
(50 \%)\end{array}$ & $\begin{array}{l}5 / 21 \\
(24 \%)\end{array}$ & $\begin{array}{c}2 / 2 \\
(100 \%)\end{array}$ & $\begin{array}{c}1 / 1 \\
(100 \%)\end{array}$ \\
\hline $\begin{array}{l}\text { Leakage control and } \\
\text { pressure regulation }\end{array}$ & $\begin{array}{c}6 / 6 \\
(100 \%)\end{array}$ & $\begin{array}{l}21 / 21 \\
(100 \%)\end{array}$ & $\begin{array}{c}2 / 2 \\
(100 \%)\end{array}$ & $\begin{array}{c}1 / 1 \\
(100 \%)\end{array}$ \\
\hline
\end{tabular}

On the issue of waste management, $59 \%$ of the establishments have implemented a clean technology or a green service (Table 4). It was determined that $100 \%$ of them have implemented waste containers labeled and differentiated by colour. Also, all establishments claim that waste is transported and managed appropriately. This is due to the fact that the Municipality of Otavalo maintains a provision to collect each type of waste separately. On Mondays, Wednesdays and Fridays organic waste is collected, and on Tuesdays, Thursdays and Saturdays inorganic waste is collected.

With regard to the application of the three Rs "reduce, reuse, recycle", only $17 \%$ of the hotels carries out this practice. Several of them comment that previously they did have within their programs tasks related to recycling, but due to the change of experienced personnel, this aspect has not been included in the new tasks and activity planning. In the other types of establishments, i.e. hostels, inns, and the refuge, the application of this practice is carried out in $38 \%, 50 \%$, and $100 \%$ respectively.

In the case of separation of organic materials, $100 \%$ of hotels, hostels, and refuges separate this type of material, while only $62 \%$ of hostelsin Otavalo carry out this practice. Also, the destination of organic material varies. Eighty-three percent of hotels deposit directly into separate containers for subsequent collection by the corresponding entity, $17 \%$ deliver the organic material to the community for home composting, and only $17 \%$ use it as compost in the establishment's green areas. In hostels these results vary since $38 \%$ deliver this waste to the community for home composting and $24 \%$ place this waste in separate containers for later collection. For hostels, $50 \%$ of organic material is stored in separate containers for its later collection, but also all these establishments use this material as compost in green areas. In the refuge, two practices are used to dispose of organic waste: depositing it directly in separate containers for subsequent collection by the corresponding entity, and using it as home compost in the green areas of the establishment. 
Table 4: Clean technologies and green services - Waste issues

\begin{tabular}{|c|c|c|c|c|c|}
\hline & & Hotel & Hostel & Inn & Refuge \\
\hline \multirow{3}{*}{ 号 } & $\begin{array}{l}\text { Waste } \\
\text { classification } \\
\text { and separation }\end{array}$ & $\begin{array}{c}6 / 6 \\
(100 \%)\end{array}$ & $\begin{array}{l}21 / 21 \\
(100 \%)\end{array}$ & $\begin{array}{c}2 / 2 \\
(100 \%)\end{array}$ & $\begin{array}{c}1 / 1 \\
(100 \%)\end{array}$ \\
\hline & $\begin{array}{l}\text { Waste } \\
\text { management } \\
\text { and transport }\end{array}$ & $\begin{array}{c}6 / 6 \\
(100 \%)\end{array}$ & $\begin{array}{l}21 / 21 \\
(100 \%)\end{array}$ & $\begin{array}{c}2 / 2 \\
(100 \%)\end{array}$ & $\begin{array}{c}1 / 1 \\
(100 \%)\end{array}$ \\
\hline & $\begin{array}{l}\text { Application of } \\
\text { the three Rs }\end{array}$ & $\begin{array}{c}4 / 6 \\
(67 \%)\end{array}$ & $\begin{array}{l}4 / 21 \\
(19 \%)\end{array}$ & $\begin{array}{l}0 / 2 \\
(0 \%)\end{array}$ & $\begin{array}{l}0 / 1 \\
(0 \%)\end{array}$ \\
\hline \multirow{3}{*}{ 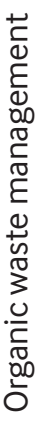 } & $\begin{array}{l}\text { Direct disposal } \\
\text { in containers }\end{array}$ & $\begin{array}{c}5 / 6 \\
(83 \%)\end{array}$ & $\begin{array}{l}5 / 21 \\
(24 \%)\end{array}$ & $\begin{array}{c}1 / 2 \\
(50 \%)\end{array}$ & $\begin{array}{c}1 / 1 \\
(100 \%)\end{array}$ \\
\hline & $\begin{array}{l}\text { Delivery for } \\
\text { home } \\
\text { composting }\end{array}$ & $\begin{array}{c}1 / 6 \\
(17 \%)\end{array}$ & $\begin{array}{l}8 / 21 \\
(38 \%)\end{array}$ & $\begin{array}{l}0 / 2 \\
(0 \%)\end{array}$ & $\begin{array}{l}0 / 1 \\
(0 \%)\end{array}$ \\
\hline & $\begin{array}{l}\text { Composting for } \\
\text { green areas of the } \\
\text { establishment }\end{array}$ & $\begin{array}{c}1 / 6 \\
(17 \%)\end{array}$ & $\begin{array}{l}1 / 21 \\
(5 \%)\end{array}$ & $\begin{array}{c}2 / 2 \\
(100 \%)\end{array}$ & $\begin{array}{c}1 / 1 \\
(100 \%)\end{array}$ \\
\hline
\end{tabular}

\section{Green actions, technologies and services of interest to accommodation establishments}

With regard to the training topics considered necessary, it was noted that they differed according to the type of establishment. In hotels, 83\% are interested in energy saving, 67\% in the ISO 14001 standard and in environmental awareness and communication for tourists. In hostels, 57\% opted for the ISO 14001 standard and energy saving, and $43 \%$ for environmental awareness for tourists. In all the hostels, training on energy saving and environmental awareness is considered necessary. For the owners of the refuge, it is of interest to raise tourist awareness of environmental issues. This shows the interest of most establishments in training their staff on environmental issues. However, this interest does not coincide with the priority topics of the Tourism and Local Economic Development Department of Otavalo, which has carried out mandatory training in good manufacturing practices, customer service, sales, and languages.
From the point of view and experience of the establishments' managers, there are certain clean technologies and green services with greater acceptance to be implemented in the hotel sector, which are presented in Table 5.

\section{Table 5: Clean technologies and green servi- ces with greater acceptance to be implemen- ted in the hotel sector of Otavalo}

\begin{tabular}{|c|c|c|}
\hline Energy & Water & Waste \\
\hline $\begin{array}{l}\text { - LED lamps } \\
\text { - Low-consumption } \\
\text { electrical appliances }\end{array}$ & $\begin{array}{l}\text { - Leakage control } \\
\text { and pressure } \\
\text { regulation }\end{array}$ & $\begin{array}{l}\text { - Waste containers } \\
\text { labeled and } \\
\text { differentiated } \\
\text { by color }\end{array}$ \\
\hline -Large windows & $\begin{array}{l}\text { - Shower flow } \\
\text { restrictors }\end{array}$ & - Waste separation \\
\hline $\begin{array}{l}\text { - Automated on/off } \\
\text { controls systems for } \\
\text { lighting }\end{array}$ & $\begin{array}{l}\text { - Gardens with } \\
\text { native plant } \\
\text { species } \\
\text { - Irrigation schedules } \\
\text { according to the } \\
\text { weather }\end{array}$ & \\
\hline
\end{tabular}

For energy issues, $100 \%$ of managers consider that LED lamps are an excellent technology, which provides benefits of saving and care for the environment. Eighty percent opted for the purchase of low-consumption electrical appliances, as well as the use of large windows (Figure 3). The owner of the El Indio Inn hotel, an establishment recognized by national and international tourists, mentions that the use or design of large windows should be considered in the design of the hotel, but not to install them in a general way in the whole facade. From his experience, he considers that rooms with a darker atmosphere should be available, since there are tourists who attend accommodation establishments for relaxation purposes, so they expect to obtain a quiet and opaque atmosphere to achieve these expectations. To conclude, $47 \%$ of establishments consider the implementation of automated on/off control systems for lighting. The least accepted technologies are air conditioning systems and renewable energies. In the case of air conditioning systems, since this is the Andean region where this study was conducted, this type of technology is not a priority. But, in the case of renewable energies, it 
is determined that there should be a greater emphasis on the diffusion of the investment benefits that these alternative energies entail. As mentioned before, both the professionals interviewed, and in the bibliography consulted, state that Ecuador is a country with good possibilities to generate energy based on solar panels, causing less environmental impacts, and being environmentally responsible.

Figure 3. Clean technologies and green services selected by Managers to be implemented - Energy issues $(n=30)$

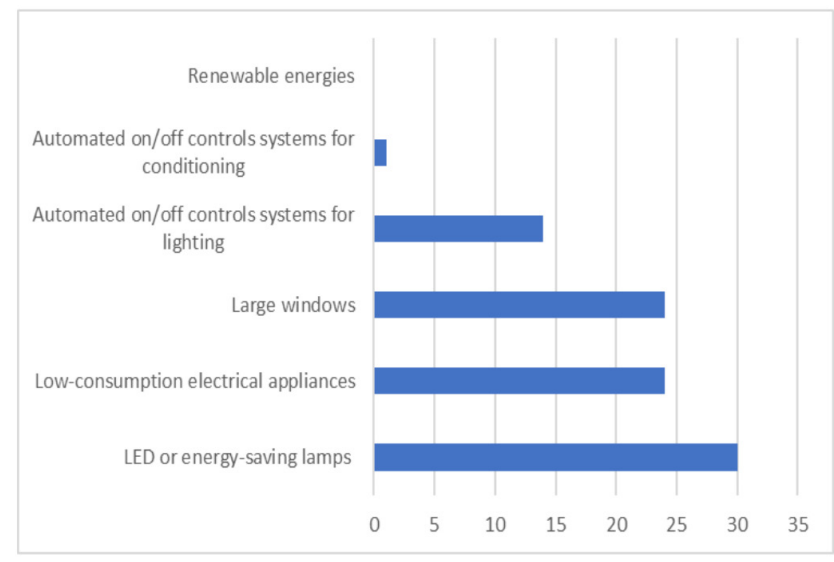

As far as water is concerned, $100 \%$ of managers agree that leakage control and pressure regulation are essential measures for achieving savings and caring for water resources. Among 47\%, another green measure is mentioned such as the design of gardens or green areas with native plants adapted to natural conditions. Forty percent also agree with the establishment of irrigation schedules to avoid water evaporation. As far as clean technologies are concerned, the percentage of acceptance is quite low, as is the case for the use of flow regulators $(10 \%)$, and sensor activated taps (3\%), but it is the shower flow restrictors that have the greatest impetus for their possible implementation, with $83 \%$ (Figure 4).
Figure 4. Clean technologies and green services selected by Managers to be implemented - Water issues $(n=30)$

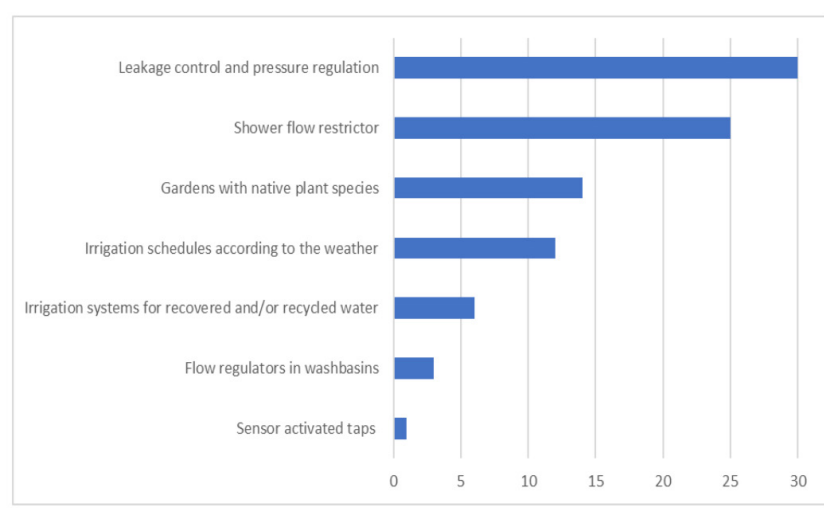

For the solid waste issue, $100 \%$ agree to use containers labeled and differentiated by color, noting that it is a necessary measure to provide within the environmental framework. The separation of materials is considered by $93 \%$, while the application of the three Rs is considered by $33 \%$ (Figure 5).

Figure 5. Clean technologies and green services selected by Managers to be implemented - Waste issues $(n=30)$

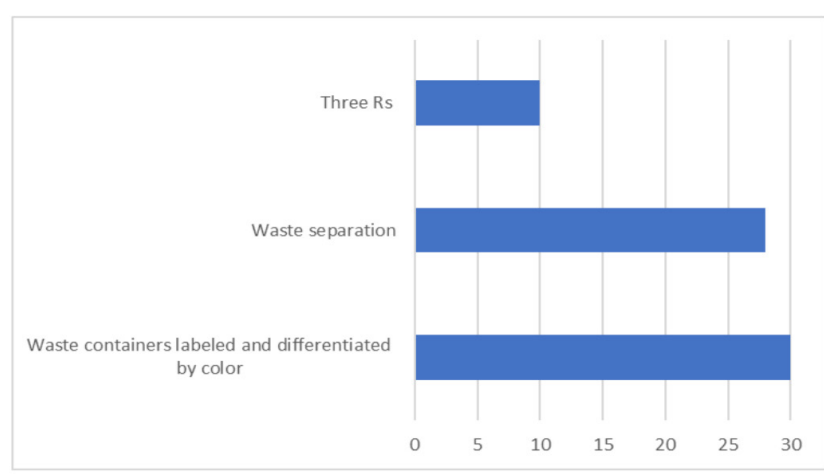

\section{Satisfaction with the clean technologies and green services implemented in the establishments}

The overall average satisfaction of all establishments, regardless of type, in the energy issue was $4.60 / 5$, showing that the clean technologies and green services that have already been implemented, and are being used in the accommodations, have been advantageous from the experience of managers. In this case, the best satisfaction scores are for LED lamps, large windows and low-consumption electrical appliances (Table 6). 
Satisfaction on the water issue was $4.70 / 5$, a high rating that indicates that the benefits of technologies and services aimed at more efficient water use are also well seen by managers. This is in spite of the fact that their level of implementation is lower than that of energy-oriented technologies and services. The technology that received the highest rating wasflow regulators, with total satisfaction from the respondents.

Finally, for the waste issue, the average satisfaction was $4.10 / 5$, slightly lower than the previous issues. Its most representative score is for the use of labeled/differentiated containers and for the separation of materials.

\section{CONCLUSIONS}

This research allowed to obtain an initial diagnosis of the environmental management in the accommodation establishments of the city of Otavalo, specifically of the clean technologies and green services present in hotels, hostels, inns, and refuge. For the energy issue there are: LED or energy saving lamps (100\%), large windows (87\%), low consumption electrical appliances (80\%), automated on/ off controls systems for lighting (43\%), and for air conditioning (3\%). In the water issue there are: leakage controls and pressure regulation (100\%), design of gardens and green areas with native plants adapted to natural conditions (50\%), establishment of irrigation schedules suited to the weather (37\%), irrigation systems for recovered and/or recycled water (23\%), flow regulators in washbasins (10\%), shower flow restrictors (17\%), and sensor activated taps (3\%). Finally, with respect to waste, the location of materials in containers that are labeled and differentiated by colour (100\%), the transport of materials to suitable spaces by the entity in charge (100\%), and the application of the practice of the three Rs (37\%) were identified.
Table 6. Satisfaction with the clean technologies and green services in the hotel sector of Otavalo

\begin{tabular}{|c|c|c|c|}
\hline & Clean technologies and green services & Av. & S.D. \\
\hline \multirow{5}{*}{ Energy } & LED or energy-saving lamp & 4.73 & \pm 0.45 \\
\hline & Low-consumption electrical appliances & 4.29 & \pm 0.62 \\
\hline & Automated on/off control systems for lighting & 4.21 & \pm 0.89 \\
\hline & Automated on/off control systems for air conditioning & 3.00 & - \\
\hline & Large windows & 4.64 & \pm 0.76 \\
\hline \multirow{7}{*}{ Water } & Perlators in washbasins & 5.00 & \pm 0.00 \\
\hline & Gardens with native plant species & 4.50 & \pm 0.76 \\
\hline & Irrigation systems for recovered and/or recycled water & 3.83 & \pm 0.98 \\
\hline & Sensor activated taps & 3.00 & - \\
\hline & Shower flow restrictors & 4.46 & \pm 0.51 \\
\hline & Irrigation schedules according to the weather & 4.50 & \pm 0.67 \\
\hline & Leakage control and pressure regulation & 4.60 & \pm 0.50 \\
\hline \multirow{4}{*}{ Waste } & Waste containers labeled and differentiated by color & 4.17 & \pm 0.83 \\
\hline & Waste classification and separation & 4.18 & \pm 0.77 \\
\hline & Waste management and transport & 3.96 & \pm 0.87 \\
\hline & Application of the three Rs & 3.80 & \pm 0.92 \\
\hline
\end{tabular}

In the future, hoteliers are considering the implementation of: LED lamps, low-consumption electrical appliances, large windows, sensors or automatic on/off lighting systems; leakage control and pressure regulation, shower flow restrictors, design of gardens or green areas with native plants, establishment of irrigation schedules in accordance with the weather, waste containers labeled and differentiated by colour, and separation of materials.

The general satisfaction of the clean technologies and green services that have been implemented up until the research development, has a final score of $4.5 / 5$; quite an encouraging value according to the experiences provided by each type of establishment in Otavalo, on clean technologies and green services. Therefore, it is required that from the different levels of State (local, regional, national), that policies are established to promote the implementation of these technologies and services in the tourism sector.

\section{REFERENCES}

Acosta Véliz, M., Lovato Torres, S., \& Buñay Cantos, J. (2018). La responsabilidad social corporativa y su rol en las empresas ecuatorianas. Revista Lasallista de Investigación, 15(2), 105-117. https://doi. org/10.22507/rli.v15n2a8 
Aravena, V. (2019). Focos ahorradores: ¿Cuál es el mejor del 2020? Retrieved from REVIEWBOXmx website: https://www.reviewbox.com.mx/focos-ahorradores/

Bedoya, L., Bejarano, J., \& Bedoya, C. (2017). Responsabilidad social corporativa como referente hacia la elaboración de memorias de sostenibilidad en Europa. Revista Facultad de Ciencias Económicas Administrativas y Contables, 7, 1-166.

Broche-Fernández, Y., \& Ramos-Gómez, R. (2015). Procedimiento para la gestión de los residuos sólidos generados en instalaciones hoteleras cubanas. Ingeniería Industrial, 36(2), 224-235.

Centro de Comercio Internacional. (2019). Tecnologías verdes. Retrieved from Organismos de las Naciones Unidas website: http://www.intracen.org/itc/ sectores/tecnologias-verdes/

Centro de Tecnologías Limpias. (2008). Estudio sobre tecnologías limpias y buenas prácticas ambientales aplicables al sector turístico. Paterna.

Contreras, S., \& Peñaloza, L. (2018). El talento humano y el cuidado ambiental en la industria hotelera. Revista Turismo y Sociedad, 23, 85-100. https://doi. org/https://doi.org/10.18601/01207555.n23.05

DANE. (2017). Clasificación de las actividades ambientales. In DANE.

FENERCOM. (2017). Guía de Gestión Energética en el Sector Hotelero. Madrid.

Fernández, G., Van Morlegan, C., \& Guzmán Ramos, A. (2007). Alojamientos turísticos y medio ambiente: diagnostico ambiental de los complejos de cabañas en Tandil. Argentina. Gestión Turística, 7(7), 27-37. https://doi.org/10.4206/gest.tur.2007.n7-02

Fernández, M., \& Cuadrado, R. (2011). La responsabilidad social empresarial en el sector hotelero: revisión de la literatura científica. Cuadernos de Turismo, 2011(28), 47-57.

Gobierno Autónomo Desentralizado de Otavalo. (2015). Actualización del Plan de Desarrollo y Or- denamiento Territorial del Cantón Otavalo - Provincia de Imbabura.

Henríquez, R., \& Oreste, R. (2015). Implicancias de una Responsabilidad Social Empresarial Sustentable. Revista Electrónica Gestión de Las Personas y Tecnología, 8(23), 16-27.

Instituto Tecnológico Hotelero. (2014). Guía de recomendaciones para la gestión sostenible del agua. Madrid.

Jaramillo, O. (2011). La dimensión interna de la responsabilidad social en las micro, pequeñas y medianas empresas del programa expüpyme de la Universidad del Norte. Pensamiento \& Gestión, (31), 167-195.

Jiménez, I., \& Segura, H. (2015). Eficiencia del ahorro energético y reducción del impacto ambiental negativo de la tecnología led. Revista de Ingeniería, Matemáticas y Ciencias de La Información, 2(3), 51-58.

Juvinao, D., \& Reines, D. (2013). Gestión de Tecnologías Verdes como elemento minimizador del Impacto Ambiental. Ecodiseño \& Sostenibilidad, 5(5), 158-167.

Lalander, R. (2009). Dilema intercultural y lucha indígena en Otavalo, Ecuador. Anales Nueva Época, (12), 108-134.

Lastra-Bravo, X. B., Coloma Martínez, J. G., Espinosa Jarrín, D., \& Herrera Ronquillo, F. (2015). Las energías renovables en la actividad turística. Innovaciones hacia la sostenibilidad. Siembra, 2(1), 86-94. https://doi.org/10.29166/siembra.v2i1.1445

López Robles, C., Calderón Gómez, G., \& López Robles, F. de A. (2012). La industria hotelera y el medio ambiente. El caso de la Isla de Ciudad del Carmen, Campeche. Retrieved from http://www.colparmex. org/Revista/Art17/74.pdf

Ministerio de Turismo. (2019). Catastro Consolidado Nacional.

Molina-Azorín, J. F., Claver-Cortés, E., Pereira-Moliner, J., \& Tarí, J. J. (2009). Environmental practices and firm performance: an empirical analysis in the Spanish hotel industry. Journal of Cleaner Production, 
17(5), 516-524. https://doi.org/10.1016/j.jclepro.2008.09.001

Paz, Y., \& Acosta, T. (2015). Evaluación de la gestión ambiental del hotel Brisas Covarrubias mediante la integración de indicadores económicos y ambientales. Ciencia En Su PC, 2(2), 43-55.

Rainforest Alliance, SNV, \& Counterpart International. (2008). Guía de Buenas Prácticas de Turismo Sostenible para Comunidades de Latinoamérica.

Realpe Sandoval, F., \& Benítez Bastías, N. (2015). Perfil del turista que ocupa la planta hotelera del cantón
Otavalo y difusión a través de un boletín estadístico informativo, Ecuador. RIAT: Revista Interamericana de Medioambiente y Turismo, 11(2), 105-135. https://doi.org/10.4067/315.

Rischmagui, G. (2017). Manual de manejo de desechos solidos en barrios populares de Tegucigalpa.

Terry, C. (2002). Producción más limpia en el sector turístico. Medio Ambiente y Desarrollo; Revista Electrónica de La Agencia de Medio Ambiente, 2(3).

Vallina Crespo, J. (2008). Los hoteles y el medio ambiente. Ecoeficiencia y buenas prácticas ambientales en hoteles. 